\title{
BMJ Global Health The foreign gaze: authorship in academic global health
}

\author{
Seye Abimbola (1) 1,2
}

To cite: Abimbola S. The foreign gaze: authorship in academic global health. BMJ Global Health 2019;4:e002068. doi:10.1136/ bmjgh-2019-002068

Received 9 0ctober 2019 Accepted 9 October 2019
Check for updates

(C) Author(s) (or their employer(s)) 2019. Re-use permitted under CC BY-NC. No commercial re-use. See rights and permissions. Published by BMJ.

${ }^{1}$ School of Public Health, University of Sydney, Sydney, New South Wales, Australia ${ }^{2}$ The George Institute for Global Health, Sydney, New South Wales, Australia

Correspondence to Dr Seye Abimbola; seyeabimbola@hotmail.com
I was really interested in black readership. For me the parallel is black music, which is as splendid and complicated and wonderful as it is because its audience was within; its primary audience. The fact that it has become universal, worldwide, anyone, everyone can play it, and it has evolved, was because it wasn't tampered with, and editorialised, within the community. So, I wanted the literature that I wrote to be that way. I could just go straight to where the soil was, where the fertility was in this landscape. And also, I wanted to feel free not to have the white gaze in this place that was so precious to me...

$$
\text { —Toni Morrison (1931-2019) }{ }^{1}
$$

And I have spent my entire writing life trying to make sure that the white gaze was not the dominant one in any of my books. The people who helped me most arrive at that kind of language were African writers... Those writers who could assume the centrality of their race because they were African. And they didn't explain anything to white people... "Things Fall Apart" [by Chinua Achebe] was more important to me than anything only because there was a language, there was a posture, there were the parameters. I could step in now, and I didn't have to be consumed by or concerned by the white gaze.

\section{-Toni Morrison (1931-2019) ${ }^{2}$}

\section{INTRODUCTION}

There is a problem of gaze at the heart of academic global health. It is difficult to name. Replace the word 'white' in the Toni Morrison quotes above with the word 'foreign', and you may see what I mean. Better still, read on. Because without naming this problem, we cannot have holistic discussions on imbalances in the authorship of academic global health publications. Recent bibliometric analyses $^{3-6}$ (some of which have been published in BMJ Global Health ${ }^{7-9}$ ) confirm patterns that are largely explained by entrenched power asymmetries in global health partnershipsbetween researchers in high-income countries (often the source of funds and agenda) and those in middle-income and especially low-income countries (where the research is often conducted). But we cannot talk about authorship without grappling with who we are as authors, who we imagine we write for (ie, gaze), and the position or standpoint from which we write (ie, pose).

It is tempting to proffer specific or direct solutions to these imbalances in authorship (some have appeared in BMJ Global Health, and we welcome more) with initiatives that include having journals, funders, universities and their governing bodies mandate the inclusion of local authors, change academic promotion criteria so that foreign experts can more readily give up choice authorship positions, provide resources to low-income and middle-income country academics to engage more equitably in partnerships, change the criteria for authorship so that more roles are recognised, and increase the diversity of journal editorial boards. $^{8-15}$ In my view, these measures are, in many cases, necessary. But I often wonder if (without addressing the problem of gaze) these solutions can result in moral licensing-that is, can the self-congratulation that will very likely accompany having these measures in place make us excuse ourselves from addressing more fundamental issues of authorship?

This editorial is based on my experiences as a journal editor, and also an academic who has been a local researcher and a foreign researcher. ${ }^{16}$ It is also based on a constructed "ideal'" of how things might have been without global health research partnerships, and when (circa late 19th to mid-20th century) many of the countries that are now high-income countries experienced significant improvements in health outcomes and equity, ${ }^{18}$ that is, an 'ideal' of local people writing about local issues for a local audience. I deploy this 'ideal' not as a prescription, but only as a heuristic device. And by applying this sense of 'ideal', I wrestle, rhetorically, with three questions that come to mind and give me pause, whenever I consider solutions to imbalances 
in authorship, especially those solutions that are based on mandates and strictures. The questions are: (1) What if the foreign gaze is necessary? (2) What if the foreign gaze is inconsequential? (3) What if the foreign gaze is corrupting?

\section{WHAT IF THE FOREIGN GAZE IS NECESSARY?}

This question stems from the notion that the requirement for balance in authorship in global health research partnerships is not self-evident. The research questions addressed in such partnerships may be best posed by foreign experts, and their findings best written for a foreign gaze. In such a situation, does it matter if the authorship is skewed towards or entirely foreign experts? While the local gaze is important, we cannot presume that the 'ideal' of local people writing about local issues for a local audience will always hold. And because such a situation in which the foreign gaze is necessary should be an exception rather than the rule, perhaps such papers should be so labelled by the lead author 'written with a foreign pose for a foreign gaze', with the justification for such an exceptional choice of pose and gaze clearly and visibly articulated in the paper. Perhaps in a box, just below the list of authors, or as a footnote, next to conflict of interests.

Let us explore one such potential scenario. Take for example, a hypothetical paper written by a foreign expert, about burial practices in West Africa. This academic was deployed as part of a team of anthropologists to support efforts to address an Ebola outbreak. Through their anthropological work, this academic helped the 'foreign-led' team in West Africa make sense of local practices, thus contributing towards making strategies for adapting burial practices in the wake of the Ebola outbreak more effective-because the burial of loved ones who died from the infection is often a channel of contracting the Ebola virus. The audience for whom the paper was written would likely be other anthropologists who perform similar service in other countries working as foreigners - a role that may not exist if all such response teams were led by local experts-that is, if every country had the capacity (especially, the funds) to respond to their own outbreaks.

In an 'ideal' scenario-that is, the anthropologist is a local expert who speaks the same language as their fellow locals, with the same burial practices, and works within a team of other local experts-the paper is different: 'written with a local pose for a local gaze'. Here is a worthwhile thought experiment: how will the content, emphasis, style and framing of a paper "with a local pose for a local gaze' differ from one 'with a foreign pose for a foreign gaze'? We can extend that question to other deviations from the 'ideal' pose and gaze (see figure 1) that is, 'written with a local pose for a foreign gaze' and 'written with a foreign pose for a local gaze'. Typically, these choices are neither consciously made nor explicitly declared. But they should. Such a declaration could

\begin{tabular}{lll}
\hline \multirow{2}{*}{ Pose } & Gaze & \\
\cline { 2 - 3 } & Local & Foreign \\
\hline Local & "Ideal” & Corrupting? \\
\hline Foreign & Consequential? & Necessary? \\
\hline
\end{tabular}

Figure 1 The authorial reflexivity matrix, with combinations of local and foreign pose and gaze.

function as a short form of authorial reflexivity, and help academics, foreign and local, to be more deliberate in their choices and attitudes, and help readers to better place the purpose of a paper.

This authorial reflexivity can give permission to the foreign expert, who, recognising the limits of what they can see or understand, chooses to write for other foreign experts, primarily; and can expose the hubris of a foreign expert who does otherwise. But note that the local versus foreign pose can shift depending on the person and the topic; an anthropologist from the same West African country, but of a different ethnicity to the location of the outbreak, may be a foreigner in relation to burial practices-foreignness could be defined by ethnicity, race, caste, geography, socioeconomic status and the issue in question. The declared authorial reflexivity can also help readers or bibliographers understand the reasoning behind the pose and gaze-for example, there is no local (with capacity) available, the pose and/or gaze does not matter, the message is best suited for a foreign audience, or the lead author knows too little to have anything of value to say to local experts.

\section{WHAT IF THE FOREIGN GAZE IS INCONSEQUENTIAL?}

The alternative, longer, form of this question is: "what if it is indeed the local (rather than the foreign) gaze that is consequential?' (see figure 1). To explore its implications, let us return to our foreign anthropologist in West Africa, but one who chooses to write primarily for local experts-that is, 'with a foreign pose for a local gaze', in an effort to approximate the ideal-that is, 'with a local pose for a local gaze'. Such a paper would be published where our 'ideal' paper is published: in local journals, many of which may not be indexed in global databases or published in English, ${ }^{19}$ but contain publications addressing research questions and policy issues that would exist, irrespective of the presence and influence of foreign experts, foreign funds, foreign donors, foreign helpers or foreign collaborators. Just consider the sheer volume of such publications. Indeed, most academic global health papers are local, ${ }^{20}$ many of them in outlets that are deemed 'predatory'. 21

How consequential is this minority of academic global health publications written for the foreign gaze? It is almost certain that local output is much more consequential, if only because sustainable progress in global health is homegrown, with local processes being responsible for much historical improvements in global health outcomes and equity ${ }^{23-27}$-and, for example, there is as 
yet no association between the density of papers in global databases on universal health coverage from a country and its attainment by the country. ${ }^{28}$ What gets written for the foreign gaze reflects the appetite of the foreign gaze ${ }^{29-35}$ which is more attuned to the 'surgical' than to the 'organic'. ${ }^{36}$ It is much easier to see 'surgical' change (as the agents of change are tangible, short-term, often external) than it is to see 'organic' change (as the agents of change are diffuse, long-term, typically internal). We must get better at recognising and explaining long-term change. ${ }^{37}$

Papers written for the foreign gaze represent only a slice of reality; only a subset of publications originating from a country that may advance the cause of global health in that country. In some cases, it is an important slice, but a slice, nonetheless. Too much focus on this subset unduly emphasises discrete, short-term and episodic efforts, often initiated or led from outside. But emerging evidence from several low-income and middle-income countries suggests that long-term change is brought about by local process, policies and dynamics-for example, the role of women's empowerment in explaining long-term change in child health outcomes. ${ }^{38-41}$ It is unfair, and even misleading and colonial to pay undue attention to the foreign gaze. And if the academic literature to which we give priority does not reflect that local experts are at the forefront of addressing local problems, then there is something deeply wrong with that literature, because it does not reflect reality.

We must rethink our attitude to 'local' journals and take some responsibility for why many local experts publish in 'predatory' journals. ${ }^{21}{ }^{22}$ If we are keen about the local gaze, we will seek to publish our work in the same journals where local experts exchange ideas; local journals and outlets will have their proper place in our imagination, and perhaps some of the shady entrepreneurs behind predatory journals may have founded legitimate peer-reviewed journals instead. ${ }^{21} 22$ Why, for example, should it be normal that a trial of strategies to reduce maternal mortality in rural India gets published in a journal based in Boston or London instead of Bangalore? Perhaps, we should extend our authorial reflexivity, so that it includes the justification for the choice of a foreign journal-for example, because it is a multicountry study, the findings are irrelevant to a local audience, funder's expectation, the journal's impact factor, or for promotion, grants and prestige.

\section{WHAT IF THE FOREIGN GAZE IS CORRUPTING?}

This question has particular resonance for me and many people I know. To explain what I mean, let us return again to our anthropologist; this time, a local anthropologist, who, although a local expert, chooses to write primarily for a foreign audience. As pose is often determined by the gaze of the spectator, the foreign gaze can alter the local expert's pose. The choice that a local expert makes about the audience that they want to inform or impress can corrupt their message (see figure 1). The local expert makes a trade-off-between on the one hand, the need to tell it like it is, and on the other hand, an effort to globalise the use of language, to make their message intelligible to an audience with little background knowledge, to sanitise the reality that they wish to convey, to hide the dirty linen. When the foreign gaze wins over, as it often does, complexity, nuance and meaning (eg, about local burial practices) can be lost, especially for the local audience.

The foreign gaze can make a local expert write like an expatriate-as often detectable in the language of local experts who work closely with foreign experts, or of postcolonial literary fiction written for the foreign gaze. ${ }^{42}$ Further, this phenomenon can also corrupt the local expert's own sense of reality-in the process of massaging, simplifying and altering reality, the local expert stands the chance of also losing their own sense of reality; the sense of complexity and of multidimensional reality that is often necessary to address delivery problems in global health. ${ }^{43}$ An additional corrupting influence of preoccupation with the foreign gaze is that it can distract (especially) local experts from engaging in the often consequential and often non-academic conversations in their own setting, some of which are not had in the English language, which should be at the centre of academic global health discourse, but unfortunately are often not taken as seriously. ${ }^{44}$

The most important conversations about health policy, systems and delivery in many low-income or middle-income countries do not make their way into peer-reviewed journals (whether local or global), and, perhaps, neither should they. I glean them on email listservs, local newspapers, local blogs, local radio, WhatsApp groups and even on Twitter. It would be both colonial and anachronistic to expect or require that such conversations be had in global journals, which many of the participants do not read and should not be expected to read. ${ }^{44}$ But it should also be unacceptable, that, like ships in the night, local and global conversations often pass each other by. The challenge is to create channels through which the content of some of these conversations can make their way into the academic global health literature, channels that can help to recognise, amplify and draw insight from local conversations without, extractively, asking for them to move to foreign platforms.

To make global health truly global is to make global health truly local. Perhaps what our local anthropologist who is keen to write for a foreign gaze must do is write two versions of the same paper-one written from a foreign pose for a foreign gaze, and another written from a local pose for a local gaze, for example, a local newspaper or blog, perhaps in a local language. ${ }^{44}$ And in the version written from foreign pose for a foreign gaze, the local expert should explain the reasoning behind that choice and the impact of the foreign gaze on their pose, on their prose, their language, their style, on what they chose to include and exclude in their paper, on the 
aspects of reality that they left out, and where the local audience might find the version written for them. The local expert may do this in a statement, as part of the declaration on authorial reflexivity, inside the box, just below the list of authors, or as an extension of the footnote, next to conflict of interests.

\section{CONCLUSION}

In many ways, the growing concerns about imbalances in authorship are a tangible proxy for concerns about power asymmetries in the production (and benefits) of knowledge in global health. In fact, authorship per se is not the fundamental issue; undoing what those imbalances represent-a continuity of the colonial project in global health-is often the issue. And the ongoing discussions on authorship in academic global health is an opportunity to have the necessary conversations that go beyond mere representation on lists of authors-through open self-reflections or reflexivity (about which much can be learnt from ongoing efforts to decolonise anthropology ${ }^{45-47}$ ), aided by the 'authorial reflexivity matrix' (see figure 1), on the situations that lead us to make less than 'ideal' choices about authorship, why those choices are sometimes necessary, how to make our work in those less than 'ideal' situations more consequential, and our choices less corrupting.

For me, the implications of the three questions explored in this editorial are inescapable. The foreign gaze is inevitable. In a globalising world, our destinies are interlinked, and the origins of and solutions to delivery problems in global health can be local or foreign. But in a world of power and information asymmetries, we see differently and understand differently; and much too often, the power to act is not directly proportional to the information on which to act. ${ }^{48}$ There will always be gaps between what local experts see and what foreign experts can possibly see. ${ }^{16}$ But more and open conversations on the place of the foreign gaze, of local knowledge and of organic (rather than surgical) change in global health are-and can help us identify other-strategies to fundamentally undo colonial practices and attitudes. The proposed reflexivity statements can be a starting pointbut only in the hope that, in this case, sunlight may, in fact, be the best disinfectant.

Twitter Seye Abimbola @seyeabimbola

Acknowledgements Many thanks to my spouse and to my friends and colleagues who listened to me talk about the ideas in this editorial as they developed and/or read previous drafts of the editorial - for their indulgence, their encouragement and their comments.

Funding The authors have not declared a specific grant for this research from any funding agency in the public, commercial or not-for-profit sectors.

Competing interests The author is the Editor in Chief of BMJ Global Health

Patient consent for publication Not required.

Provenance and peer review Not commissioned; internally peer reviewed.

Data availability statement There are no data in this work

Open access This is an open access article distributed in accordance with the Creative Commons Attribution Non Commercial (CC BY-NC 4.0) license, which permits others to distribute, remix, adapt, build upon this work non-commercially, and license their derivative works on different terms, provided the original work is properly cited, appropriate credit is given, any changes made indicated, and the use is non-commercial. See: http://creativecommons.org/licenses/by-nc/4.0/.

\section{ORCID iD}

Seye Abimbola http://orcid.org/0000-0003-1294-3850

\section{REFERENCES}

1 Australian Broadcasting Corporation (ABC). Toni Morrison interviewed by Jana Wendt, 1998. Available: https://www.youtube. $\mathrm{com} /$ watch?v=WoTELoC8Q0M

2 Public Broadcasting Service (PBS). Toni Morrison - interviewed by Charlie Rose, 1998. Available: https://charlierose.com/videos/17664

3 Kelaher M, Ng L, Knight K, et al. Equity in global health research in the new millennium: trends in first-authorship for randomized controlled trials among low- and middle-income country researchers 1990-2013. Int J Epidemiol 2016;45:2174-83.

4 Chersich MF, Blaauw D, Dumbaugh M, et al. Local and foreign authorship of maternal health interventional research in low- and middle-income countries: systematic mapping of publications 20002012. Global Health 2016:12:35

5 Rees CA, Lukolyo H, Keating EM, et al. Authorship in paediatric research conducted in low- and middle-income countries: parity or parasitism? Trop Med Int Health 2017;22:1362-70.

6 Cash-Gibson L, Rojas-Gualdrón DF, Pericàs JM, et al. Inequalities in global health inequalities research: a 50-year bibliometric analysis (1966-2015). PLoS One 2018:13:e0191901.

7 Schneider H, Maleka N. Patterns of authorship on community health workers in low-and-middle-income countries: an analysis of publications (2012-2016). BMJ Glob Health 2018;3:e000797.

8. Boum IIY, Mbaye R, Gebeyehu R, et al. Who's telling the story? A systematic review of authorship for infectious disease research conducted in Africa, 1980-2016. BMJ Glob Heal 2019;4:e001855.

9 Hedt-Gauthier B, Jeufack H, Neufeld N, et al. Stuck in the middle: a systematic review of authorship in collaborative health research in Africa, 2014-16. BMJ Glob Heal 2019;4:e001853.

10 Boum II Y, Burns BF, Siedner M, et al. Advancing equitable global health research partnerships in Africa. BMJ Glob Health 2018;3:e000868.

11 Hedt-Gauthier B, Airhihenbuwa CO, Bawah AA, et al. Academic promotion policies and equity in global health collaborations. The Lancet 2018;392:1607-9.

12 Carvalho A, IJsselmuiden C, Kaiser K, et al. Towards equity in global health partnerships: adoption of the research Fairness initiative (RFI) by Portuguese-speaking countries. BMJ Glob Health 2018;3:e000978.

13. The Lancet Global Health. Closing the door on parachutes and parasites. Lancet Glob Health 2018;6:e593.

14 Bhaumik S, Jagnoor J. Diversity in the editorial boards of global health journals. BMJ Glob Heal 2019;4:e001909.

15 Nafade V, Sen P, Pai M. Global health journals need to address equity, diversity and inclusion. BMJ Glob Heal 2019;4:e002018.

16 Gilmore B. Realist evaluations in low-income and middle-income countries: reflections and recommendations from the experiences of a foreign researcher. BMJ Glob Heal 2019;4:e001638.

17 Appiah KA. As if: Idealization and ideals. Cambridge, MA: Harvard University Press, 2017.

18 Cutler D, Deaton A, Lleras-Muney A. The determinants of mortality. $J$ Econ Perspect 2006;20:97-120.

19 MoChridhe R. Linguistic equity as open access: Internationalizing the language of scholarly communication. J Acad Librarian 2019;45:423-7.

20 Sgrò A, Al-Busaidi IS, Wells Cl, et al. Global surgery: a 30-year bibliometric analysis (1987-2017). World J Surg 2019;43:2689-98.

21 Shen C, Björk B-C. 'Predatory' open access: a longitudinal study of article volumes and market characteristics. BMC Med 2015;13:230.

22 Frandsen TF. Are predatory journals undermining the credibility of science? A bibliometric analysis of citers. Scientometrics 2017;113:1513-28.

23 Szreter S. The Importance of Social Intervention in Britain's Mortality Decline c .1850-1914: a Re-interpretation of the Role of Public Health. Soc Hist Med 1988;1:1-38.

24 De Brouwere V, Tonglet R, Van Lerberghe W, et al. Strategies for reducing maternal mortality in developing countries: what can we learn from the history of the industrialized West? Trop Med Int Health 1998;3:771-82. 
25 Fairchild AL, Rosner D, Colgrove J, et al. The exodus of public health what history can tell us about the future. Am J Public Health 2010;100:54-63.

26 Bhatia A, Krieger N, Subramanian SV. Learning from history about reducing infant mortality: contrasting the centrality of structural interventions to early 20th-century successes in the United States to their neglect in current global initiatives. Milbank Q 2019;97:285-345.

27 Medcalf AJ, Bhattacharya S, Momen H, et al. Health for all: the journey of universal health coverage. Hyderabad, IN: Orient Blackswan, 2015

28 Gheorghe A, Chalkidou K, Culyer A. How concentrated are academic publications of countries' progression towards universal health coverage? Lancet Glob Health 2019;7:e696-7.

29 Storeng KT, Béhague DP. "Guilty until proven innocent": the contested use of maternal mortality indicators in global health. Crit Public Health 2017;27:163-76.

30 Chambers R. Biases and blind spots. In: Chambers R, ed. Can we know better? Hyderabad, IN: Practical Action Publishing Ltd, 2017: 27-56.

31 Roalkvam S, McNeill D. What counts as progress? the contradictions of global health initiatives. Forum Dev Stud 2016;43:69-88.

32 Jerven M. Beyond precision: embracing the politics of global health numbers. The Lancet 2018;392:468-9.

33 Rajkotia Y. Beware of the success cartel: a plea for rational progress in global health. BMJ Glob Health 2018;3:e001197.

34 Bédécarrats F, Guérin I, Roubaud F. All that glitters is not gold. The political economy of randomized evaluations in development. Dev Change 2019;50:735-62.

35 Storeng KT, Abimbola S, Balabanova D, et al. Action to protect the independence and integrity of global health research. BMJ Glob Health 2019;4:e001746.

36 Lewis CS. The abolition of man. Oxford: Oxford University Press, 1943.
37 Rosling H, Rosling O, Rönnlund AR. Factfulness: ten reasons we're wrong about the world - and why things are better than you think. New York, NY: Flatiron Books, 2018.

38 Keats EC, Macharia W, Singh NS, et al. Accelerating Kenya's progress to 2030: understanding the determinants of under-five mortality from 1990 to 2015. BMJ Glob Health 2018;3:e000655.

39 Nguyen $\mathrm{PH}$, Scott S, Avula R, et al. Trends and drivers of change in the prevalence of anaemia among 1 million women and children in India, 2006 to 2016. BMJ Glob Health 2018;3:e001010.

40 Rahman A, Rahman M, Pervin J, et al. Time trends and sociodemographic determinants of preterm births in pregnancy cohorts in Matlab, Bangladesh, 1990-2014. BMJ Glob Health 2019;4:e001462.

41 Dwomoh D, Amuasi S, Agyabeng K, et al. Understanding the determinants of infant and under-five mortality rates: a multivariate decomposition analysis of demographic and health surveys in Ghana, 2003, 2008 and 2014. BMJ Glob Health 2019;4:e001658.

42 Adesokan A. New African writing and the question of audience. Research in African Literatures 2012;43:1-20.

43 Abimbola S. On the meaning of global health and the role of global health journals. Int Health 2018;10:63-5.

44 Saha S, Afrad MMH, Saha S, et al. Towards making global health research truly global. Lancet Glob Health 2019;7:e1175.

45 Jacobs-Huey $L$. The natives are gazing and talking back: reviewing the problematics of positionality, voice, and accountability among "native" anthropologists. Am Anthropol 2002;104:791-804.

46 Smith LT. Decolonizing methodologies: research and Indigenous peoples. 2nd edn. London: Zed Books, 2012.

47 Harrison FV. Decolonizing anthropology: moving further toward an anthropology for liberation. 3rd edn. Arlington: American Anthropological Association and the Association of Black Anthropologists, 2011.

48 Abimbola S. The information problem in global health. BMJ Glob Health 2016;1:e900001. 